\title{
Gene Therapy in Tissue-Engineered Blood Vessels*
}

\author{
RYAN C. FIELDS, B.S., ${ }^{1}$ AMY SOLAN, M.S., ${ }^{2}$ KEVIN T. MCDONAGH, M.D., ${ }^{3}$ \\ LAURA E. NIKLASON, M.D., Ph.D., ${ }^{2}$ and JEFFREY H. LAWSON, M.D., Ph.D. ${ }^{1}$
}

\begin{abstract}
Cardiovascular disease is the leading cause of morbidity and mortality in Western society. More than 1 million arterial bypass procedures are performed annually in the United States, where either autologous veins or synthetic grafts are used to replace arteries in the coronary or peripheral circulation. Tissue engineering of blood vessels from autologous cells has the potential to produce biological grafts for use in bypass surgery. Ex vivo development of vascular grafts also provides an ideal target of site-specific gene therapy to optimize the physiology of the developing conduit, and for the possible delivery of other therapeutic genes to a vascular bed of interest. In this article, we demonstrate that by using a novel retroviral gene delivery system, a target gene of interest can be specifically delivered to the endothelial cells of a developing engineered vessel. Further, we demonstrate that this technique results in stable incorporation of the delivered gene into the target endothelial cells for more than 30 days. These data demonstrate the utility of the retroviral gene delivery approach for optimizing the biologic phenotype of engineered vessels. This also provides the framework for testing an array of genes that may improve the function of engineered blood vessels after surgical implantation.
\end{abstract}

\section{INTRODUCTION}

C Aardiovascular Disease is the leading cause of morbidity and mortality in Western society. Some 1.4 million arterial bypass procedures performed annually in the United States require autologous vein or synthetic grafts to replace arteries in the coronary or peripheral circulation. ${ }^{1,2}$ Tissue engineering of blood vessels from autologous cells has the potential to produce biological grafts for use in vascular and cardiac surgery. This could pave the way for producing an array of autologous arteries that would be suitable for bypass procedures in patients who lack any other suitable conduit. ${ }^{3,4}$

Our laboratory has developed techniques for culturing tissue-engineered arteries from vascular cells of adult an- imals. Using these techniques, we have cultured and implanted autologous tissue-engineered vascular grafts in a cohort of miniature swine. However, thrombosis is a frequent cause of graft failure in this and other models of tissue-engineered blood vessels. ${ }^{5-7}$ In various studies, graft occlusion can occur anywhere from 1 day to 4 weeks after implantation. Hence, thrombosis remains a key limiting factor in the success of engineered vessels.

Endothelial cells (ECs) that are placed in culture often downregulate expression of many anticoagulant and antiinflammatory molecules that are expressed on native, quiescent endothelium. ${ }^{8}$ In contrast, many procoagulant and proinflammatory molecules, including tissue factors such as vascular cell adhesion molecule 1 (VCAM-1), and intercellular adhesion molecule 1 (ICAM-1), are up-

\footnotetext{
${ }^{1}$ Department of Surgery and Pathology, Duke University Medical Center, Durham, North Carolina.

${ }^{2}$ Department of Anesthesia and Biomedical Engineering, Duke University Medical Center, Durham, North Carolina.

${ }^{3}$ Department of Internal Medicine, University of Michigan Medical Center, Ann Arbor, Michigan.

${ }^{*}$ Part of this work was presented at the $2^{\text {nd }}$ Annual Conference on Arteriosclerosis, Thrombosis, and Vascular Biology, Arlington, Virginia, May 2001.
} 
regulated in culture in response to a variety of factors. ${ }^{9-11}$ Hence, it is likely that cultured ECs seeded onto the lumens of engineered blood vessels exhibit a proinflammatory, procoagulant phenotype, which ultimately contributes to graft thrombosis. In this regard, it would be useful to develop a method to manipulate the phenotype expressed on vascular ECs. However, stable transfection of ECs is known to be problematic. Viral transfection efficiencies with ECs are reportedly low, ${ }^{12-15}$ and longterm expression in ECs is difficult to retain. ${ }^{16-18}$

The long-term goal of this work is to enable overexpression of anticoagulant proteins on the surface of vascular ECs that are used to seed engineered vascular grafts. As a first step toward this aim, we developed a vector capable of stably delivering a transgene of interest to ECs that are derived from multiple species. We show that retroviral transgene expression is stable in ECs in vitro, and is retained by ECs in situ on the lumens of engineered blood vessels.

Although we have developed this methodology to address the problem of thrombosis, these retroviral techniques may be extended to deliver any therapeutic gene of interest in a tissue-engineered blood vessel. Because blood vessels are in constant, direct contact with the bloodstream, therapeutic gene products could be stably delivered to the host, using this technique. Hence, stable retroviral gene transfer in engineered blood vessels could have broad impact in the fields of both gene therapy and controlled drug delivery.

\section{MATERIALS AND METHODS}

\section{Target cell lines and culture media}

Porcine aortic ECs (PAECs) were harvested from the aortas of naive pigs (Charles River Laboratories, Wilmington, MA). Briefly, the aortas of sacrificed pigs were dissected free of surrounding tissues and placed in Dulbecco's modified eagle's medium (DMEM; GIBCO, Grand Island, NY) under sterile conditions. The vessel was then opened lengthwise and bathed in $1 \%$ collagenase (Sigma, St. Louis, MO) for 5 min. ECs were harvested by gentle rolling of a wooden swab over the lumenal surface, and cultured in "standard growth medium," which was DMEM with $20 \%$ fetal bovine serum (FBS; HyClone, Logan, UT), 4 mM L-glutamine, penicillin-streptomycin $(10 \mathrm{U} / \mathrm{mL})$, porcine-derived heparin $(1 \mathrm{U} / \mathrm{mL})$ (all from GIBCO), and endothelial cell growth supplement (ECGS, $15 \mathrm{mg} / \mathrm{mL}$; Sigma). Endothelial cell morphology was visualized by light microscopy as well as by positive uptake of fluorescently labeled acetylated low-density lipoprotein (LDL) (Molecular Probes, Eugene, OR) and negative staining of smooth muscle $\alpha$-actin (Sigma). Cells were used between passages 4 and 10 in all experiments.
Human umbilical vein ECs (HUVECs) and NIH 3T3 cells were obtained from the American Tissue Culture Collection (ATCC, Manassas, VA). Human microvascular ECs (HMECs) were obtained from the Centers for Disease Control (CDC, Atlanta, GA). HUVECs and HMECs were maintained in MCDB-131 (GIBCO) medium with $20 \%$ FBS, $4 \mathrm{mM}$ L-glutamine, penicillin-streptomycin $(10 \mathrm{U} / \mathrm{mL})$, porcine-derived heparin $(1 \mathrm{U} / \mathrm{mL})$, and ECGS $(15 \mathrm{mg} / \mathrm{mL})$. NIH 3 T3 cells were maintained in DMEM with $10 \%$ FBS, 2 mM L-glutamine, and penicillin-streptomycin $(10 \mathrm{U} / \mathrm{mL})$.

Porcine smooth muscle cells for engineered blood vessel growth were isolated from the carotid artery of Yucatan miniature swine. ${ }^{19}$ Briefly, the lumenal material of the artery was thoroughly removed by vigorous scraping with a scalpel. Tissue segments were then placed lumen-side down onto a tissue culture dish and allowed to adhere for a period of 7 days. At that time, the tissue was peeled away with sterile forceps and the attached smooth muscle cells were maintained in culture. The smooth muscle cell medium was DMEM (JRH Biosciences, Lenexa, KS) with $10 \%$ penicillin-streptomycin (GIBCO), 10\% FBS, HEPES (2.6 mg/mL; JRH Biosciences), proline $(50 \mu \mathrm{g} / \mathrm{mL})$, alanine $(20 \mu \mathrm{g} / \mathrm{mL})$, glycine $(50 \mu \mathrm{g} / \mathrm{mL})$, penicillin $\mathrm{G}(100$ $\mathrm{U} / \mathrm{mL}), \mathrm{CuSO}_{4}(3 \mathrm{ng} / \mathrm{mL})$, ascorbic acid $(50 \mu \mathrm{g} / \mathrm{mL})$, basic fibroblastic growth factor $(10 \mathrm{ng} / \mathrm{mL})$, and platelet-derived growth factor-BB (10 ng/mL) (all from Sigma).

\section{Retroviral packaging cell lines}

PA $317^{20}$ and PG13 $3^{21,22}$ retroviral packaging cell lines stably expressing the pRet2.EGFP retroviral expression vector were utilized. The PG13 cell line is a retrovirus packaging cell line derived from TK-NIH 3T3 cells and based on the gibbon ape leukemia virus $(\mathrm{GaLV}){ }^{3}$ The PA317 cell line was derived from TK-NIH 3T3 cells by cotransfection with packaging construct DNA (pPAM3) and the herpes simplex virus thymidine kinase gene, both carried in pBR322. Introduction of retroviral vectors into these cells, by infection or by transfection, results in production of retrovirus virions with an amphotropic host range that are capable of infecting cells of many mammalian species.

Both the PA317 and the PG13 cell lines were transfected with ecotropic Phoenix-E packaging cells carrying the plasmid pRet2.EGFP. pRet2.EGFP is a modified version of the retroviral backbone MFG retroviral vector designed to optimize gene expression in primary cell lines, ${ }^{5}$ and expressing enhanced green fluorescent protein (EGFP). Both cell lines were maintained in DMEM supplemented with $10 \%$ FBS, 2 mM L-glutamine, and penicillin-streptomycin $(10 \mathrm{U} / \mathrm{mL})$.

\section{Adenoviral transfection of target cells}

First-generation E1/E3-deleted replication-deficient serotype 5 adenoviruses were kindly provided by W.J. 
Koch and were used as previously described. ${ }^{23,24}$ The marker transgenes $\beta$-galactosidase and EGFP were driven by the cytomegalovirus promoter. Adenoviral particles $\left(10^{7}\right)$ were used to infect one confluent well of target ECs in a 6-well culture plate.

\section{Retrovirus isolation and infection of target cells}

Cultures of PA317 and PG13 packaging cell lines transfected with the above-described construct were grown to subconfluency. Retroviral supernatant was harvested and passed through a $0.45-\mu \mathrm{m}$ pore size filter to remove cellular debris. Viral supernatant was then added at varying dilutions in $2 \mathrm{~mL}$ of total medium supplemented with protamine sulfate $(5 \mathrm{mg} / \mathrm{mL})$ to $1 \times 10^{5}$ target cells (PAECs, HUVECs, HMECs, and NIH 3 T3 cells) in 6-well culture plates. Infection cultures were carried out for $24 \mathrm{~h}$. Virus-containing medium was then aspirated off the plates and cells were washed three times with phosphate-buffered saline (PBS), and then maintained in culture for 4-10 days. When cells became confluent, they were analyzed for infection efficiency by assessing EGFP expression.

\section{Infection analysis}

Starting on culture day 4, cells were imaged by fluorescence microscopy using standard filters. Infection efficiency was quantified via flow cytometry. Cells were trypsinized and analyzed on a FACScan (BD Biosciences Immunocytometry Systems, San Jose, CA) (excited by 488-nm light, using a 549-nm bandpass filter on FL1) to determine the percentage of cells expressing EGFP. To analyze long-term expression, day 7 cultures of infected PAECs were sorted on a FACSCalibur (BD Biosciences Immunocytometry Systems). These cells, considered to be $100 \%$ GFP positive, were maintained in culture for up to 30 days. At various time points, cells were harvested and analyzed via flow cytometry for EGFP expression.

To assess adenoviral transfection efficiency at 5-day intervals, duplicate wells infected with Adeno- $\beta$-gal were fixed in $0.5 \%$ glutaraldehyde in $50 \%$ PBS for 5 min at room temperature, and then stained with $10 \mathrm{mM}$ $\mathrm{K}_{4} \mathrm{Fe}(\mathrm{CN})_{6} / 10 \mathrm{mM} \mathrm{K}{ }_{3} \mathrm{Fe}(\mathrm{CN})_{6} / 2 \mathrm{mM} \mathrm{MgCl} / 5$-bromo-4chloro-3-indolyl $\beta$-D-galactopyranoside (X-Gal, $1 \mathrm{mg} / \mathrm{mL}$ ) in PBS for $30 \mathrm{~min}$ at $37^{\circ} \mathrm{C}$ as described. ${ }^{25}$ The staining solution then was aspirated and the cells were permanently fixed in $1.5 \%$ glutaraldehyde in 50\% PBS. Transfection efficiency was determined by enumerating the percentage of cells staining blue per high-power field averaged over 20 high-power fields per well.

\section{Generation of tissue-engineered blood vessels}

Polyglycolic acid (PGA) (Albany International, Albany, $\mathrm{NY}$ ) polymeric scaffolds, ${ }^{26} 1 \mathrm{~mm}$ in thickness and having 96\% void volume, were sewn around silicone tubing (Nor- ton Performance Plastics, Beaverton, MI). PGA scaffolds were $3 \mathrm{~mm}$ in diameter and $7 \mathrm{~cm}$ in length. Scaffolds and tubing were then inserted into glass bioreactors for vessel culture (James Glass, Hanover, MA). After bioreactor sterilization, $3 \times 10^{6}$ smooth muscle cells (SMCs) at passage 3 were seeded onto PGA scaffolds. The medium for vessel culture was DMEM (JRH Biosciences) with $10 \%$ penicillin-streptomycin (GIBCO), 10\% FBS, HEPES (2.6 $\mathrm{mg} / \mathrm{mL}$; JRH Biosciences), proline (50 $\mu \mathrm{g} / \mathrm{mL})$, alanine (20 $\mu \mathrm{g} / \mathrm{mL})$, glycine $(50 \mu \mathrm{g} / \mathrm{mL})$, penicillin $\mathrm{G}(100 \mathrm{U} / \mathrm{mL})$, $\mathrm{CuSO}_{4}(3 \mathrm{ng} / \mathrm{mL})$, ascorbic acid $(50 \mu \mathrm{g} / \mathrm{mL})$, basic fibroblastic growth factor $(10 \mathrm{ng} / \mathrm{mL})$, and platelet-derived growth factor-BB (10 ng/mL) (all from Sigma).

Engineered blood vessels were mechanically stretched using pulsatile fluid flow through the center of the silicone tube, as previously described. ${ }^{27}$ Pulse rates for engineered constructs were maintained at 90 beats/min (bpm). Fresh medium was supplied once a week, and gas exchange was provided through filters on the tops of the bioreactors (Cole-Parmer, Vernon Hills, IL). Vessel culture continued for 7 weeks at $37^{\circ} \mathrm{C}$ and $10 \% \mathrm{CO}_{2}$, after which time the center silicone tube was removed from the lumen of the engineered construct in preparation for endothelialization.

\section{Seeding of engineered blood vessels with GFP- expressing endothelial cells}

On day 7 postinfection, PAECs infected with PG13derived vector were harvested and sorted for high GFP expression as described above. To ensure robust gene expression, only PAECs demonstrating EGFP expression 2 standard deviations above nontransfected levels were used to seed the vessel lumen. PAECs were replated at $10^{6}$ cells $/ \mathrm{mL}$ in $75-\mathrm{cm}^{2}$ culture flasks for $48 \mathrm{~h}$ in standard growth medium. PAECs were then trypsinized, and $10^{7}$ cells were resuspended in $2.5 \mathrm{~mL}$ of standard growth medium, and the suspension was injected into the lumen of the engineered blood vessel. Cells were allowed to attach to the lumenal surface for 90 min under static conditions. A pulsatile pump (Cole-Parmer) then perfused EC standard culture medium through the lumen. Flow was controlled to approximate venous blood flow with shear rates increased to $3.6 \mathrm{dyn} / \mathrm{cm}^{2}$ over the course of $24 \mathrm{~h}$. Endothelial cell culture continued for a total of $72 \mathrm{~h}$. After EGFP-expressing PAECs were cultured in engineered blood vessels, the vessels were removed from the culture system and processed for frozen sectioning. Vessel segments were visualized for EGFP fluorescence with a Zeiss microscope, and images were acquired via an Axiovert 135 digital camera.

\section{Statistical analysis}

Results are shown as averages \pm SEM. Significance was determined by Student's $t$ test, with a threshold of $p<0.05$. 


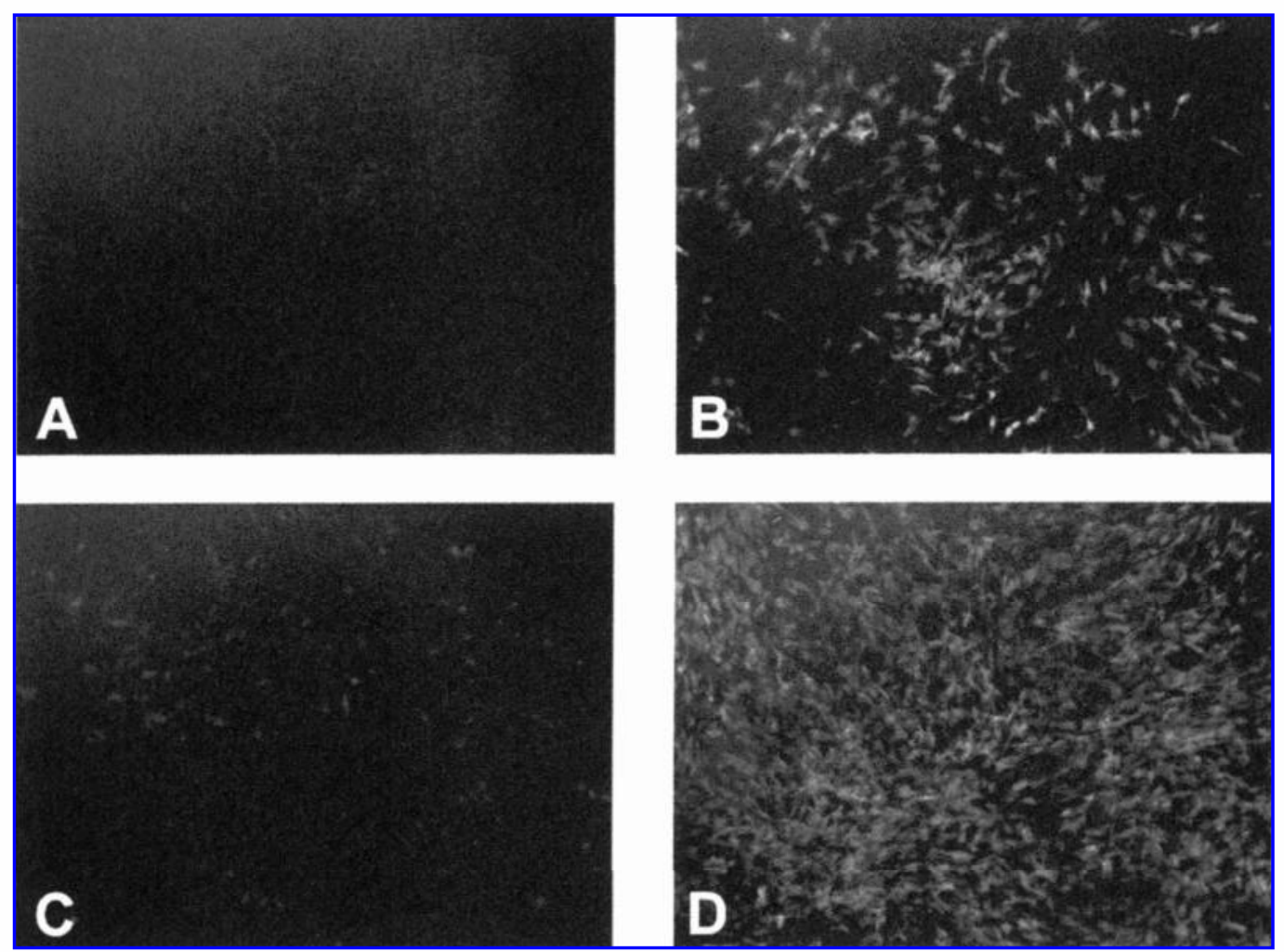

FIG. 1. EGFP expression in cultured ECs, 7 days after initial infection with PG13-derived retroviral vector. (A) NIH 3 T3 cells, not infected with vector, serving as a negative control; (B) HMECs; (C) HUVECs; (D) PAECs. Original magnification: (A-D) $\times 10$.

\section{RESULTS}

\section{Retroviral transfer is efficient in ECs}

Retroviral constructs derived from both PA317 and PG13 packaging cell lines demonstrated excellent ability to infect ECs in vitro. EGFP expression was visualized as early as day 4 via fluorescence microscopy, and was maximal on day 7 (Fig. 1). PG13-derived retroviral vector infected HMECs, HUVECs, and PAECs with good efficiency as indicated by fluorescence microscopy.

Qualitative impressions of infection efficiency were confirmed by quantitative flow cytometry results (Fig. 2). Infection efficiencies were studied in HUVECs, HMECs, PAECs, and NIH 3T3 cells. Apart from NIH 3 T3 cells, retroviral vectors derived from both packaging lines infected all types of ECs studied with high efficiency. In particular, PA317- and PG13-derived constructs infected PAECs with similar efficiency. The PA317 construct was chosen for further studies in PAECs of retained EGFP expression, and engineered vessel seeding.

\section{Retroviral EC gene expression is superior to adenoviral}

We studied the long-term stability of transgene products in PAECs that were transfected with Adeno- $\beta$-gal and PG13-derived retroviral construct. PAECs treated with both vectors were monitored for 30 days of culture by flow cytometry (Fig. 3). Cells infected with PG13-derived retrovirus retained EGFP with $85 \%$ efficiency after 30 days, whereas cells infected with adenovirus retained either EGFP or $\beta$-galactosidase at significantly

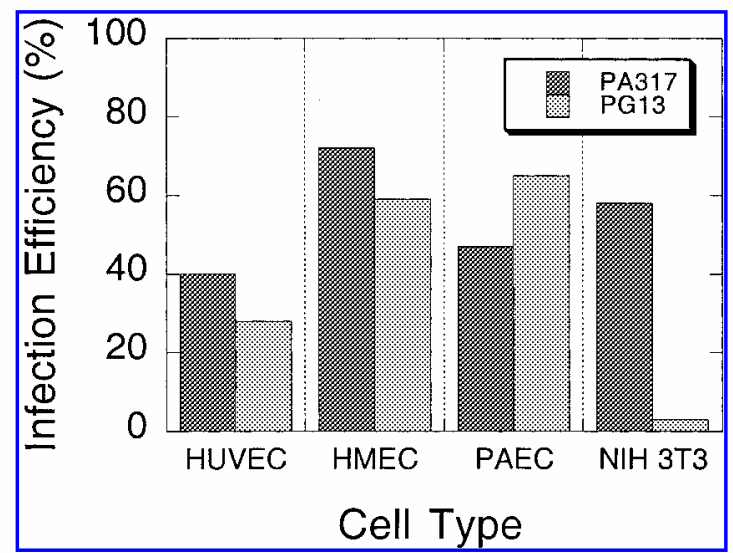

FIG. 2. Efficiency of EGFP expression. Percentage of cells strongly expressing EGFP after infection with both PA317- and PG13-derived retroviruses (dark and light columns, respectively). Overall infection efficiency is high for multiple EC types, and is similar between two vectors. 


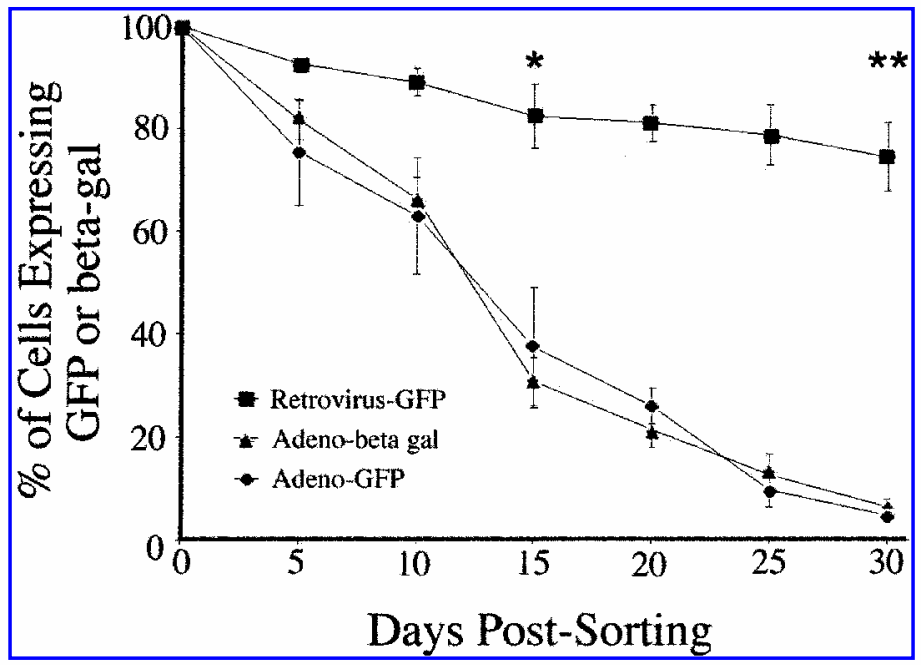

FIG. 3. Retention of adenoviral versus retroviral gene products. PAECs monitored for 30 days in culture exhibited decrement in transgene expression, but PG13-derived retrovirus resulted in significantly greater expression (versus both EGFP and $\beta$-Gal) than adenovirus at 15 days $\left({ }^{*} p<0.05\right)$ and 30 days $\left({ }^{* *} p<0.001\right)$.

lower levels ( 5 and $8 \%$ of cells, respectively, after 30 days; $p<0.05$ on day $15, p<0.001$ on day 30 when compared with PG13-derived retrovirus). When continued in culture past 30 days, GFP expression was maintained but PAEC replication substantially diminished, possibly reflecting the known finite life span of cultured ECs in vitro. ${ }^{28}$

\section{Expression of EGFP in situ in ECs of engineered blood vessels}

To verify the applicability of this approach to engineered grafts, we cultured porcine vessels under pulsatile conditions. After endothelialization with EGFP-expressing PAECs, vessels were harvested from bioreactors and prepared for frozen sectioning. Eight-micron sections were examined by fluorescence microscopy. A dense layer of GFP-expressing cells lined the lumenal vessel surface (arrows, Fig. 4), demonstrating the feasibility of this gene transfer approach to tissue-engineered blood vessels.

\section{DISCUSSION}

The field of tissue engineering is developing at a rapid rate. Design of artificial tissues offers a means to replace a variety of diseased body parts, including cartilage, bone, bladder, and blood vessel. ${ }^{6,29-32}$ Because of the prevalence of vascular disease, vascular tissue engineering has the potential to affect a large portion of the adult population. The effective design of engineered vascular prostheses also could present the opportunity to deliver engineered cells or molecules of interest directly to the bloodstream.

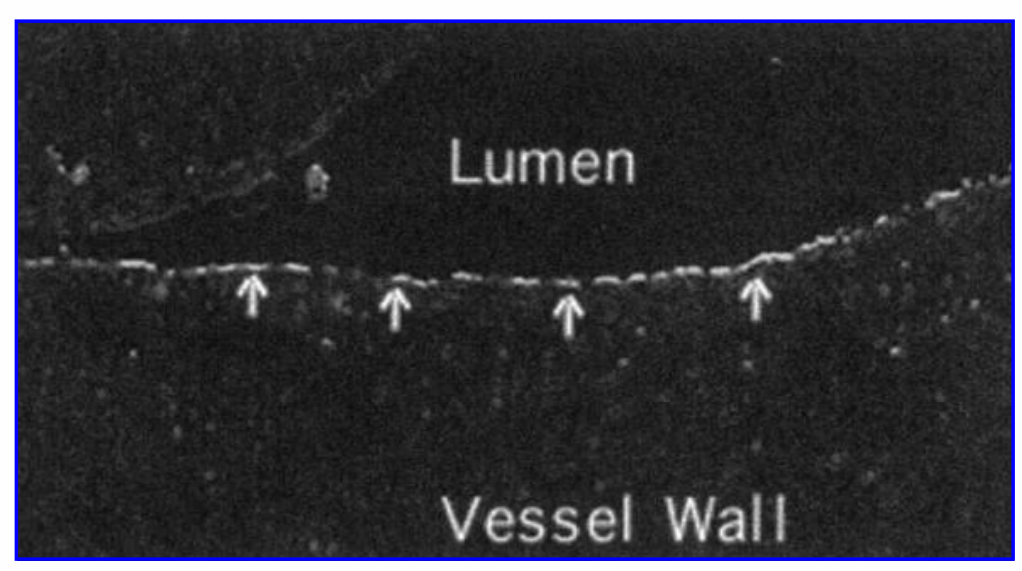

FIG. 4. EGFP is expressed on engineered vessel lumen. Arrows indicate PAEC monolayer expressing EGFP. Vessel wall and lumen are indicated. 
To date, the critical limitation in successful implementation of artificially designed blood vessels is the high rate of vessel thrombosis., ${ }^{6,73}$ The adhesion, density, and phenotype of the endothelial layer in the vessel is responsible for its thrombogenic potential. ${ }^{34}$ Molecules expressed by the ECs, such as tissue factor, can actively promote coagulation, while loss of endogenous anticoagulants such as thrombomodulin can increase thrombosis risk. Thus, modulation of the endothelial cell phenotype may represent a means to prevent vessel failure by thrombosis, both in tissue-engineered constructs and potentially in native arteries.

One way to alter the phenotype of the ECs is by the introduction of a gene of interest, but stable transfection of ECs has often been problematic. Gene transfection has been used as a therapeutic measure in both the liver and the pulmonary system. ${ }^{35,36}$ Other previous studies have indicated that transient (i.e., 10-20 days) EC transfection may be a useful means to control the thrombogenicity rate of the vasculature. ${ }^{37}$ In this article we have demonstrated the ability to stably infect ECs with a marker gene encoding enhanced green fluorescent protein. Infection efficiencies exceeded $60 \%$, and illustrated the feasibility of using this technique for ECs derived from a variety of sources. Protein expression was preserved over time ( $>30$ days) and in tissue-engineered vessels, indicating the potential for continued expression in vivo.

Thrombomodulin (TM) may represent a good potential target for overexpression, because if its inhibitory effect on tissue factor in the coagulation cascade. ${ }^{38}$ Loss of TM expression in implanted venous grafts has been indicated as a cause of decreased resistance to thrombosis. ${ }^{39}$ In order for TM overexpression to have physiologic impact in a porcine model, however, the species-specific gene sequence is required. Previous studies have shown that species discordance in the TM cascade can decrease enzymatic efficiency by two orders of magnitude. ${ }^{40,41}$ Hence, for antithrombotic molecules in this pathway to be bioactive in vivo, the porcine gene product is required. To this end, the porcine thrombomodulin gene is currently being closed for future infection.

We have demonstrated the potential power of EC gene therapy combined with tissue engineering. A tissue-engineered blood vessel may be the optimal gene delivery or drug delivery vehicle. Endothelial cell gene expression allows direct access to the blood stream for the therapeutic molecule of interest. This technology could be extended to other therapeutic genes such as thrombolytics or hormones. Gene therapy combined with vascular tissue engineering is a potentially powerful therapeutic tool for the treatment of human disease.

\section{ACKNOWLEDGMENTS}

We gratefully acknowledge Dr. Walter J. Koch for adenoviral constructs. This study was supported in part by a
North Carolina Biotechnology Center Grant (2001-ARG0041; L.E.N.), a Duke University Translational Research Award (J.H.L. and L.E.N.), the Department of Surgery, Duke University, and the NHLBI (HL63766; L.E.N.). A.S. is supported by an NIH Cellular and Biosurface Engineering Training Grant (5T32 GM-08555-08).

\section{REFERENCES}

1. Langer, R., and Vacanti, J. Tissue engineering. Science 260, 920, 1993.

2. Connolly, R., Anderson, J.M., Kambic, H.E., Griesler, H., and Merrill, I.W. Small diameter vascular prostheses. ASAIO J. 34, 1043, 1988.

3. Topol, E., and Serruys, P. Frontiers in interventional cardiology. Circulation 98, 1802, 1998.

4. Lefkowitz, R.J., and Willerson, J. Prospects for cardiovascular research. JAMA 285, 57, 2001.

5. Niklason, L. unpublished (2002).

6. Niklason, L.E., Gao, J., Abbott, W.M., Hirschi, K.K., Houser, S., Marini, R., and Langer, R. Functional arteries grown in vitro. Science 284, 489, 1999.

7. L'Heureux, N., Paquet, S., Labbe, R., Germain, L., and Auger, F.A. A completely biological tissue-engineered human blood vessel. FASEB J. 12, 47, 1998.

8. Wu, K., and Thiagarajan, P. Role of endothelium in thrombosis and hemostasis. Annu. Rev. Med. 47, 315, 1996.

9. Lin, M., Almus-Jacobs, F., Chen, H.H., Parry, G.C.N., Mackman, N., Shyy, J., and Chien, S. Shear stress induction of the tissue factor gene. J. Clin. Invest. 99, 737, 1997.

10. Allen, S., Khan, S., Mohanna, F., Batten, P., and Yacoub, M. Native low density lipoprotein-induced calcium transients trigger VCAM-1 and E-selectin expression in cultured human vascular endothelial cells. J. Clin. Invest. 101, 1064, 1998.

11. Carlos, T., and Harlan, J. Leukocyte-endothelial adhesion molecules. Blood 84, 2068, 1994.

12. Nathwani, A.C., Gale, K.M., Pemberton, K.D., Crossman, D.C., Tuddenham, E.G.D., and McVey, J.H. Efficient gene transfer into human umbilical vein endothelial cells allows functional analysis of the human tissue factor promoter. $\underline{B r}$. J. Haematol. 88, 122, 1994.

13. Teifel, M., Heine, L., Milbredt, S., and Friedl, P. Optimization of transfection of human endothelial cells. Endothelium 5, 21, 1997.

14. Edgell, C.S., Curiel, D.T., Hu, P., and Marr, H.S. Efficient gene transfer to human endothelial cells using DNA complexed to adenovirus particles. Biotechniques 25, 264, 1998.

15. Tanner, F.C., Carr, D.P., Nabel, G.J., and Nabel, E.G. Transfection of human endothelial cells. Cardiovasc. Res. 35, 522, 1997.

16. Steg, P.G., Feldman, L.J., Scoazec, J., Tahlil, O., Barry, J.J., Boulechfar, S., Ragot, Thierry, Isner, J.M., and Perricaudet, M. Arterial gene transfer to rabbit endothelial and smooth muscle cells using percutaneous delivery of an adenoviral vector. Circulation 90, 1648, 1994.

17. Raja-Walia, R., Webber, J., Naftilan, J., Chapman, G.D., and Naftilan, A.J. Enhancement of liposome-mediatedgene 
transfer into vascular tissue by replication deficient adenovirus. Gene Ther 2, 521, 1995.

18. Newman, K.D., Dunn, P.F., Owens, J.W., Schulick, A.H., Virmani, R., Sukhova, G., Libby, P., and Dichek, D.A. Adenovirus-mediated gene transfer into normal rabbit arteries results in prolonged vascular cell activation, inflammation, and neointimal hyperplasia. J. Clin. Invest. 96, 2955, 1995.

19. Ross, R. The smooth muscle cell. II. Growth of smooth muscle in culture and formation of elastic fibers. J. Biol. Chem. 275, 172, 1971.

20. Miller, A., and Buttimore, C. Redesign of retrovirus packaging cell lines to avoid recombination leading to helper virus production. Mol. Cell Biol. 6, 2895, 1986.

21. Miller, A. Construction and properties of retrovirus packaging cells based on gibbon ape leukemia virus. J. Virol. 65, 2220, 1991.

22. Miller, A., and Rosman, G. Improved retroviral vectors for gene transfer and expression. Biotechniques 7, 980, 1989.

23. Akhter, S., McDonald, P.H., Peppel, K.C., Glower, D.D., Lefkowitz, R.J., and Koch, W.J. Restoration of $\beta$-adrenergic signaling in failing cardiac ventricular myocytes via adenoviral-mediated gene transfer. Proc. Natl. Acad. Sci. USA 94, 12100, 1997.

24. Maurice, J., White, D.C., McDonald, P.H., Dolber, P.C., Wilson, K.H., Lefkowitz, R.J., Glower, D.D., and Koch, W.J. Enhancement of cardiac function after adenoviral-mediated in vivo intracoronary $\beta_{2}$-adrenergic receptor gene delivery. J. Clin. Invest. 104, 21, 1999.

25. Drazner, M., Peppel, K.C., Dyer, S., Grant, A.O., Koch, W.J., and Lefkowitz, R.J. Potentiation of $\beta$-adrenergic signaling by adenoviral-mediated gene transfer in adult rabbit ventricular myocytes. J. Clin. Invest. 99, 288, 1997.

26. Freed, L.E., Vunjak-Novakovic,G., Biron, R.J., Eagles, D.B., Lesnoy, D.C., Barlow, S.K., and Langer, R. Biodegradable polymer scaffolds for tissue engineering. Biotechnology 12, 689, 1994.

27. Solan, A., Mitchell, S., Moses, M., and Niklason, L. Effect of pulse rate on collagen deposition in the tissue-engineered blood vessel. Tissue Eng. in press (2003).

28. Yang, J., Chang, E., Cherry, A., Bangs, C., Oei, Y., Bodnar, A., Bronstein, A., Chiu, C., and Herron, S. Human endothelial cell life extension by telomerase expression. J. Biol. Chem. 274, 26141, 1999.

29. Atala, A. Bladder regeneration by tissue engineering. $\mathrm{Br}$. J. Urol. 88, 765, 2001.

30. Evans, G. Challenges to nerve regeneration. Semin. Surg. Oncol. 19, 312, 2000.

31. Sittinger, M., Peka, C., Schultz, O., Haupl, T., and
Burmester, G. Joint cartilage regeneration by tissue engineering. Z. Rheumatol. 58, 130, 1999.

32. Rose, F.R., and Oreffo, R.O. Bone tissue engineering:Hope vs. hype. Biochem. Biophys. Res. Commun. 292, 1, 2002.

33. Shum-Tim, D., Stock, U., Hrkach, J., Shinoka, T., Lien, J., Moses, M., Stamp, A., Taylor, G., Moran, A., Landis, W., Langer, R., Vacanti, J., and Mayer, J. Tissue engineering of autologous aorta using a new biodegradable polymer. Ann. Thorac. Surg. 68, 2298, 1999.

34. Rosenberg, R.D., and Aird, W.C. Mechanisms of disease: Vascular-bed-specific hemostasis and hypercoagulable states. N. Engl. J. Med. 340, 1555, 1999.

35. Grossman, M., Rader, D.J., Muller, D.W.M., Kolansky, D.M., Kozarsky, K., Clark, B.J., Stein, E.A., Lupien, P.J., Brewer, H.B., Raper, S.E., and Wilson, J.M. A pilot study of ex vivo gene therapy for homozygous familial hypercholesterolemia. Nat. Med. 1, 1148, 1995.

36. Campbell, A.I.M., Kuliszewski, M.A., and Stewart, D.J. Cell-based gene transfer to the pulmonary vasculature: Endothelial nitric oxide synthase overexpression inhibits monocrotaline-induced pulmonary hypertension. Am. J. Respir. Cell Mol. Biol. 21, 567, 1999.

37. Dichek, D.A., Anderson, J., Kelly, A.B., Hanson, S.R., and Harker, L.A. Enhanced in vivo antithrombotic effects of endothelial cells expressing recombinant plasminogen activators transduced with retroviral vectors. Circulation 93, 301, 1996.

38. Esmon, N.L., Carroll, R.C., and Esmon, C.T. Thrombomodulin blocks the ability of thrombin to activate platelets. J. Biol. Chem. 258, 12238, 1983.

39. Kim, A.Y., Walinsky, P.L., Koldgie, F.D., Bian, C., Sperry, J.L., Deming, C.B., Peck, E.A., Shake, J.G., Ang, G.B., Sohn, R.H., Esmon, C.T., Virmani, R., Stuart, R.S., and Rade, J.J. Early loss of thrombodulin expression impairs vein graft thromboresistance. Circ. Res. 90, 205, 2002.

40. Lawson, J., Daniels, L., and Platt, J. The evaluation of thrombomodulin activity in porcine to human xenotransplantation. Transplant. Proc. 29, 884, 1997.

41. Lawson, J., and Platt, J. Molecular barriers to xenotransplantation. Transplant. Proc. 62, 303, 1996.

Address reprint requests to: L.E. Niklason, M.D., Ph.D.

Department of Anesthesia and Biomedical Engineering Duke University Medical Center Durham, NC 27710

E-mail: nikla001@mc.duke.edu 


\section{This article has been cited by:}

1. Achala de Mel, Capucine Bolvin, Mohan Edirisinghe, George Hamilton, Alexander M Seifalian. 2008. Development of cardiovascular bypass grafts: endothelialization and applications of nanotechnology. Expert Review of Cardiovascular Therapy 6:9, 1259-1277. [CrossRef]

2. E. Jabbarzadeh, T. Starnes, Y. M. Khan, T. Jiang, A. J. Wirtel, M. Deng, Q. Lv, L. S. Nair, S. B. Doty, C. T. Laurencin. 2008. Induction of angiogenesis in tissue-engineered scaffolds designed for bone repair: A combined gene therapy-cell transplantation approach. Proceedings of the National Academy of Sciences 105:32, 11099-11104. [CrossRef]

3. Gabriel Zarbiv, Meir Preis, Yaara Ben-Yosef, Moshe Y Flugelman. 2007. Engineering blood vessels by gene and cell therapy. Expert Opinion on Biological Therapy 7:8, 1183-1191. [CrossRef]

4. Oliver Bleiziffer, Elof Eriksson, Feng Yao, Raymund E. Horch, Ulrich Kneser. 2007. Gene transfer strategies in tissue engineering. Journal of Cellular and Molecular Medicine 11:2, 206-223. [CrossRef] 